\title{
Prevalence and Characterization of Extended Spectrum Beta Lactamase Producing Escherichia coli from Broilers
}

\author{
Susmita Pal ${ }^{1}$, Samir Dey ${ }^{*}$, Kunal Batabyal ${ }^{1}$, Abhiroop Banerjee ${ }^{2}$, \\ Siddhartha Narayan Joardar ${ }^{1}$, Indranil Samanta ${ }^{1}$ and Devi Prasad Isore ${ }^{1}$ \\ ${ }^{1}$ Department of Veterinary Microbiology, West Bengal University of Animal and Fishery \\ Sciences (WBUAFS), Belgachia, Kolkata-700037, India \\ ${ }^{2}$ West Bengal University of Animal and Fishery Sciences, Kolkata-700037, India \\ *Corresponding author
}

Keywords

Antimicrobial sensitivity, Broilers, disc, E.coli, ESBL, PCR

Article Info

Accepted:

05 February 2020

Available Online:

10 March 2020

\section{A B S T R A C T}

In the current study prevalence and characterization of extended spectrum betalactamase(ESBL) production of Escherichia coli was detected from broilers of West Bengal, India. A total of 248 cloacal swabs samples were examined for E.coli by standard bacteriological techniques. E.coli isolates were serotyped and also screened for extended spectrum beta-lactamase by double disc diffusion assay and by PCR detection of bla $b l a_{S H V}$, and $b l a_{T E M}$ genes. The antimicrobial sensitivity profile of the isolated E.coli was demonstrated against 13 antimicrobial agents. One hundred thirty one (52.82\%) E.coli were identified and the isolates belonged to 12 different serogroups viz. O2, O20, O35, O83, O87, O88, O116, O117, O119, O128, O135, O141 and untyped isolates. Thirty seven (28.24\%) of E.coli were detected as ESBL-positive by double disc diffusion assay. Among the studied genes, $b l a_{C T X-M}$ gene was detected in $32(24.43 \%), b l a_{S H V}$ gene in $3(2.29 \%)$ isolates and $b_{\text {TEM }}$ gene in $2(1.53 \%)$ isolates. Highest antimicrobial susceptibility of E.coli isolates was observed to chloramphenicol $(69.36 \%)$ and levofloxacin $(62.9 \%)$. Highest degree of resistance was observed to cefepime (95.12\%) followed by nalidixic acid $(88.88 \%)$, co-trimoxazole (83.33\%), ampicillin (79.03\%), cefotaxime (78.46\%), tetracycline $(72.58 \%)$ and ciprofloxacin $(62.90 \%)$. The present study revealed that broilers were reserviors of ESBL producing E.coli and resistant to many classes of antimicrobials.

\section{Introduction}

Escherichia coli are commensal organism in the gastrointestinal tract of warm-blooded animals and it has been extensively used to monitor antimicrobial resistance in food animals including poultry. During the past few decades, drug resistance in E.coli has increased dramatically worldwide. Diverse class of antimicrobials is used to raise poultry 
in most countries, mostly through the oral route, with the aim to prevent and treat diseases, enhance growth and productivity (Page and Gautier, 2012; Landini and Albarellos, 2015). Resistant poultry pathogens to antimicrobials may cause treatment failure leading to economic losses and were potential reservior of resistant bacterial genes that may represent a risk to human health (Nhung et al., 2017).

Antimicrobial resistance to penicillins and cefalosporins is mainly due to extendedspectrum beta-lactamase (ESBL) production. ESBL confers resistance to 3 rd- and $4^{\text {th }}$ generation cephalosporins but not to cephamycins (cefoxitin) and carbapenems, and is inactivated by clavulanic acid. The three $\beta$-lactamases CTX-M (active on cefotaxime, first isolated at Munich), SHV (sulfhydryl reagent variable) and TEM (named after the patient Temoneira) are the most important representatives of ESBL $E$. coli colonizing and infecting poultry (Olsen $e t$ al., 2014). Prevalence of ESBL producting E.coli has been reported both in human and food animal isolates (Bhoomika et al., 2016). It is uncertain whether ESBL E. coli represent a direct threat to poultry production but it certainly represents a major problem to human clinical medicine. However, there was no concensus regarding the zoonotic potential of ESBL E. coli (Olsen et al., 2014).

Past research has reported that broiler farms tend to use more antimicrobials and harbor a higher level of resistance than layer farms. In a study of Brower et al., (2017), the prevalence of ESBL-positive strains was reported higher in broiler farms than layer farms. Recently, occurrence of ESBL producing E.coli were reported in several Indian states in healthy farmed poultry and backyard poultry(Samanta et al., 2014; Samanta et al., 2015, Shrivastav et al., 2016) and other food producing animals such as pigs
(Lalzampuia et al., 2013). Very little information is currently available that addresses the prevalence of ESBLs in animals for active surveillance which can help understand the epidemiology of ESBL burden in India (Kuralayanapalya et al., 2019; Walia et al., 2019). In view of the above, the present study was performed to detect the prevalence, serotypes and antimicrobial susceptibility, ESBL-production of Escherichia coli isolates in broilers of West Bengal, India.

\section{Materials and Methods}

In the present study, 248 cloacal swabs samples were collected from poultry farms located in different districts across 2 zones of West Bengal, India viz. New alluvial and old alluvial zones. The birds were reared in intensive deep litter system of management. Samples were collected from the age group of 1 week to 5 weeks of broilers. All the collected samples were enriched with peptone water (HiMedia, India) and incubated at $37^{\circ} \mathrm{C}$ for overnight. The peptone water enriched samples were taken and a loop full of culture was streaked on MacConkey's agar (HiMedia, India) and incubated at $37^{\circ} \mathrm{C}$ for overnight. Lactose-fermenting, pink single colonies were selected and subcultured on Eosin Methylene Blue agar (HiMedia, India) plates for selective isolation. The characteristic greenish metallic sheen showing colonies were streaked on nutrient agar (HiMedia, India) slants for further morphological and biochemical characterization as per method described by Quinn et al., (1999). E.coli isolates were serogrouped at National Salmonella and Escherichia Centre, Central Research Institute, Kasauli, Himachal Pradesh, India.

\section{Phenotypic detection of ESBLs}

For all E.coli, Cefotaxime $(30 \mu \mathrm{g})$ and ceftazidime disks $(30 \mu \mathrm{g})$ with or without 
clavulanate $(10 \mu \mathrm{g})$ [HiMedia, India] were used by diffusion method for phenotypic confirmation of the presence of ESBLs in $E$. coli. A difference of $>5 \mathrm{~mm}$ between the zone diameters of either of the cephalosporin disks and their respective cephalosporin/clavulanate disk was taken for phenotypic confirmation of ESBL production (CLSI, 2017).

\section{PCR screening for ESBL genes}

PCR detection of the bla genes was performed on all isolates phenotypically positive by combination disk test. Primers (GCC Biotech, India) were used for the specific genes encoding ESBL for CTX-M, SHV and TEM families as described previously (Weill et al., 2004a, b) with little modification. The template deoxyribonucleic acid (DNA) was prepared from freshly cultured bacterial isolates by suspending 2-3 colonies in $500 \mu \mathrm{l}$ of molecular grade water as described previously(Samanta et al.,2014) with positive and negative controls. Amplification reaction mixture containing $3 \mu 1$ DNA templates, 50pmol each primer set (Table 1), 200mM deoxynucleoside triphosphate, 1U GoTaq DNA polymerase (Promega, USA), $2 \mathrm{mM} \mathrm{MgCl}_{2}$ and $10 \%$ DMSO was prepared in a $25 \mu 1$ reaction mixture and subjected to PCR amplification. Amplification was conducted in a thermocycler (Mastercycler personal, Eppendorf, Germany). The cycle condition of the PCR amplification consisted an initial denaturation of $94^{\circ} \mathrm{C}$ for $10 \mathrm{mins}$ followed by 35 cycles of denaturation at $94^{\circ} \mathrm{C}$ for $30 \mathrm{secs}$, annealing at $50^{\circ} \mathrm{C}\left(53^{\circ} \mathrm{C}\right.$ for bla $\left._{C T X-M}\right)$ for 30 secs and elongation at $72^{\circ} \mathrm{C}$ for 60 secs with a 10 mins final extension period at $72^{\circ} \mathrm{C}$. The amplified products were visualized by gel documentation system (UVP, UK) after agarose gel electrophoresis containing 1.5\% w/v agarose (SRL, India) and ethidium bromide $(0.5 \mu \mathrm{g} / \mathrm{ml})$ (SRL, India).

\section{Antimicrobial susceptibility test}

All E.coli isolates were tested for their sensitivity and resistant patterns to 13 different antimicrobial agents by the agar diffusion method in Mueller-Hinton agar (HiMedia, India). The antibiotic discs used were as amikacin, ampicillin, gentamicin, levofloxacin, ciprofloxacin, chloramphenicaol, co-trimoxazole, nalidixic acid, cefepime, cefotaxime, ceftazidime, piperacillin-tazobactam and tetracycline (HiMedia, India). The total diameter of the zone of inhibition was measured after incubation for $24 \mathrm{~h}$ at $37^{\circ} \mathrm{C}$ and recorded. The result was interpreted as sensitive, intermediate and resistant as per Clinical and Laboratory Standard Institute (2017). However, intermediate isolates were grouped with sensitive isolates for differing them from resistant. Reference E. coli ATCC 25922 was used as quality control strain for antimicrobial susceptibility test.

\section{Results and Discussion}

In the present study, one hundred thirty one $(131 / 248,52.82 \%)$ bacterial isolates were identified as E.coli (Table.2) on the basis of staining property, colony characteristics, and standard biochemical reaction. Prevalence rate $(52.82 \%)$ of E.coli in the present study was in agreement with previous studies (Joshi et al., 2012). E.coli prevalence rate of $52.63 \%$ has been reported in their study. While higher prevalence rates of $65 \%$ was detected in another study (Samanta et al., 2014). Samples that gave negative bacterial culture may be collected from farms that may have used antibiotic treatment prior to sample collection.

E. coli is considered as a member of the normal microflora of the poultry intestine, but certain strains (APEC) can spread into various internal organs and cause colibacillosis characterized by systemic fatal disease. In the 
present study, E.coli isolates belonged to 12 different serogroups viz. O2, O20, O35, O83, O87, O88, O116, O117, O119, O128, O135, $\mathrm{O} 141$ and untyped isolates. Avian colibacillosis were implicated with diverse $\mathrm{O}$ serogroups including those isolated in the present study viz.O2, O35, O88 O87, O119 and O141 (Dho-Moulin and Fairbrother, 1999; Kunert Filho et al.,2015). Other serogroups O83, O116, O117, O128, and 0135 in the present study may be commensals. In a study of Shiva Shankar et al., (2010), major serotypes recorded were O78, O75, O2, O6 and 0111 from heart blood samples $(n=120)$ of colisepticemic birds. In another study, 10 serogroups were reported from poultry and except O119 all serogruops O60, O80, O84, O95, O102, O110, O114,, $\mathrm{O} 120$ and $\mathrm{O} 132$ were different from present study (Joshi et al.,2012). Mostly different serogruops O17, O20, O22, O102, O114 of E.coli were detected except O119 from poultry cloacal swabs and poultry farm environment samples in a previous study of West Bengal (Samanta et al.,2015). The serogroups O2 and O149 were also encountered from human origin in India (Thakur et al., 2016).

Out of 131 E.coli, 37 (28.24\%) were detected ESBL-positive by double disc assay (Figure 1). Among the three bla genes, 32 (24.43\%)
E.coli isolates were found to possess blaCTX ${ }_{M}$ gene (Figure 2), 2 (1.53\%) isolates bla gene and $3(2.29 \%)$ isolates bla $a_{S H V}$ gene. In partial agreement with the current study, $29.4 \%$ of $E$. coli isolates from farmed poultry of West Bengal were found to possess ESBL genes with predominance of blaCTX-M gene $(43.4 \%)$ followed by blaSHV $(34.7 \%)$ and blaTEM (21.7\%) genes (Samanta et al., 2014). This variations may happen as there are various subgroups of ESBL genes arised from point mutations in the genes resulting in multiple subtypes. Kar et al., (2015) found much lower prevalence $(16 / 252,6.35 \%)$ multidrug resistant ESBL-producing E. coli from fecal samples of poultry from Odisha. High frequency of blaCTX-M ESBLproducing $E$. coli were reported from poultry in several European countries viz. from Poland (Wasyl et al., 2012), Germany (Laube et al., 2014), UK (Randall et al., 2011). Widespread prevalence of ESBL producing $E$. coli in broiler farms as well as emission in its surrounds was well established with $100 \%$ similar PFGE pattern (Laube et al., 2014). Despite reduced use of antimicrobials in poultry production, high prevalence of ESBL E. coli in retail chicken meat samples was noticed in France (Casella et al., 2017). However, different sampling protocols and methodologies used make comparison of data between countries incompatible.

Table.1 Oligonucleotides used in PCR for ESBL genes

\begin{tabular}{|c|c|c|c|c|}
\hline $\begin{array}{l}\text { Sl. } \\
\text { No. }\end{array}$ & $\begin{array}{l}\text { Target } \\
\text { Genes }\end{array}$ & Primer sequences $\left(5^{\prime}-3^{\prime}\right)$ & $\begin{array}{l}\text { Annealing } \\
\text { temp }\left({ }^{0} \mathrm{C}\right)\end{array}$ & Reference \\
\hline 1 & $\begin{array}{l}\text { bla }_{C T X-M} \\
\text { consensus }\end{array}$ & $\begin{array}{l}\text { Forward- AATGTGCAGCACCAAGTAA } \\
\text { Reverse-CGCGATATATCGTTGGTGGTGGTG }\end{array}$ & 53 & Weill et al., 2004a \\
\hline 2 & bla $_{S H V}$ & $\begin{array}{l}\text { Forward-TTATCTCCCTGTTAGCACC } \\
\text { Reverse-GATTTGCTGATTTCGCTCGG }\end{array}$ & 50 & Weill et al., 2004b \\
\hline 3 & bla $_{T E M}$ & $\begin{array}{l}\text { Forward- ATAAAATTCTTGAAGACGAAA } \\
\text { Reverse- GACAGTTACCAATGCTTAATC }\end{array}$ & 50 & Weill et al., 2004b \\
\hline
\end{tabular}


Table.2 Prevalence and distribution of extended spectrum betalactamase (ESBL) genes of E.coli isolates of broilers

\begin{tabular}{|l|c|c|c|c|}
\hline $\begin{array}{l}\text { Agro climatic } \\
\text { Zones } \\
\text { (sample no.) }\end{array}$ & $\begin{array}{c}\text { No. of } \boldsymbol{E} . \\
\text { coli isolates }\end{array}$ & \multicolumn{3}{|c|}{$\boldsymbol{\beta}$ lactamase positive(no.) } \\
\cline { 4 - 5 } & $(\boldsymbol{\%})$ & $b l a_{C T X-M}$ & $b l a_{S H V}$ & $b l a_{T E M}$ \\
\hline $\begin{array}{l}\text { New alluvial zone } \\
(\mathbf{1 6 2})\end{array}$ & $89(54.94)$ & 21 & 2 & 2 \\
\hline Old alluvial zone(86) & $42(48.83)$ & 11 & 1 & 0 \\
\hline Total (248) & $131(52.82)$ & $32(24.43 \%)$ & $3(2.29 \%)$ & $2(1.53 \%)$ \\
\hline
\end{tabular}

Table.3 Antimicrobial susceptibility profile of E.coli isolates of broilers

\begin{tabular}{|c|c|c|c|c|c|}
\hline \multirow{2}{*}{$\begin{array}{l}\text { Sl. } \\
\text { No. }\end{array}$} & \multirow{2}{*}{$\begin{array}{l}\text { Class of } \\
\text { antimicrobials }\end{array}$} & \multirow{2}{*}{$\begin{array}{l}\text { Antimicrobials } \\
\text { (Conc. in } \mu \mathrm{g})\end{array}$} & \multicolumn{3}{|c|}{ No. of isolates } \\
\hline & & & $\begin{array}{c}\text { Sensitive } \\
(\%)\end{array}$ & $\begin{array}{c}\text { Intermediate } \\
(\%)\end{array}$ & $\begin{array}{c}\text { Resistant } \\
(\%)\end{array}$ \\
\hline 1 & \multirow[t]{2}{*}{ Aminoglycosides } & Amikacin (30) & $55(41.94)$ & $36(27.42)$ & $40(30.65)$ \\
\hline 2. & & Gentamicin (10) & $34(25.81)$ & $42(32.26)$ & $55(41.94)$ \\
\hline 3. & \multirow[t]{5}{*}{ Beta lactams } & Ampicillin (10) & $6(4.84)$ & $19(14.52)$ & $103(79.03)$ \\
\hline 4. & & $\begin{array}{l}\text { Pipercillin- } \\
\text { Tazobactam(100/10) }\end{array}$ & $14(11.11)$ & $87(66.67)$ & $29(22.22)$ \\
\hline 5. & & Cefepime (30) & $0(0)$ & $6(4.88)$ & $125(95.12)$ \\
\hline 6. & & Cefotaxime (30) & $2(1.54)$ & $24(18.46)$ & $103(78.46)$ \\
\hline 7. & & Ceftazidime (30) & $20(15.38)$ & $81(61.54)$ & $30(23.07)$ \\
\hline 8. & Phenicols & Chloramphenicol (30) & $63(48.39)$ & $27(20.97)$ & $40(30.65)$ \\
\hline 9. & \multirow{3}{*}{$\begin{array}{l}\text { Quinolones and } \\
\text { fluoroquinolones }\end{array}$} & Nalidixic acid (30) & $7(5.41)$ & $11(8.11)$ & $116(88.88)$ \\
\hline 10. & & Ciprofloxacin (5) & $10(8.06)$ & $38(29.03)$ & $82(62.90)$ \\
\hline 11. & & Levofloxacin (5) & $57(43.55)$ & $25(19.35)$ & $49(37.09)$ \\
\hline 12. & Sulphonamides & Co-trimoxazole (25) & $18(13.88)$ & $2(1.61)$ & $116(88.88)$ \\
\hline 13. & Tetracycline & Tetracycline (30) & $23(17.74)$ & $13(9.68)$ & $95(72.58)$ \\
\hline
\end{tabular}

Figure.1 Combination disc diffusion test of representative isolate of $E$. coli 


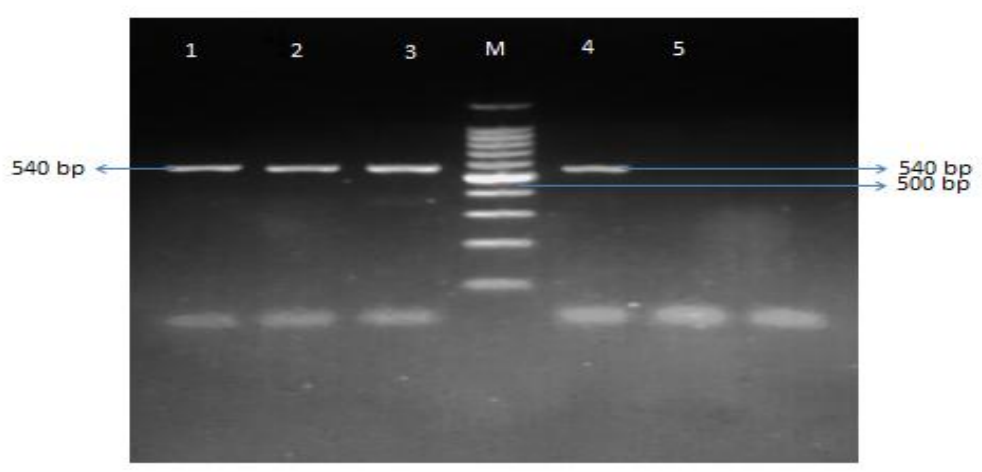

Figure 2: PCR Detection of blaCTX-M gene from ESBL $E$.coli isolates

\begin{abstract}
Lane 1 - 3, representative samples showing blaCTX-M gene positive, lane M 100bp DNA ladder, Lane 4 positive control, Lane 5-negative control(PBS)
\end{abstract}

Highest antimicrobial susceptibility of E.coli isolates was observed to chloramphenicol (48.39\%) followed by levofloxacin $(43.55 \%)$ with additional (20.97\%) and (19.35\%) isolates, respectively showed intermediate sensitivity (Table 3). High degree of resistance was observed to beta lactams viz. cefepime $(95.12 \%)$, ampicillin $(79.03 \%)$, and cefotaxime $(78.46 \%)$. Most isolates were also resistant to 3 or more classes of antimicrobials like nalidixic acid (88.88\%), ciprofloxacin $(62.90 \%)$, co-trimoxazole $(83.33 \%)$ and tetracycline $(72.58 \%)$.

Resistance of E.coli isolates to $\beta$-lactam antibiotics like cefepime (95.12\%), ampicillin (79.03\%), cetazidime (61.54\%), cefotaxime $(78.46 \%)$ in the present study was mostly because of ESBL-production. Similarly, Lazampuia et al. (2014) also recorded higher resistance to $\beta$-lactam antibiotics in 134 E.coli isolates of poultry in the state of Mizoram, India. Resistance of $E$. coli to potentiated sulphonamides (co-trimoxazole) was also reported earlier by several workers (Joshi et al., 2012; Sahoo et al., 2012; Ibrahim et al., 2019). In the present study, increasing resistance of $E$. coli to quinolones and fluoroquinolones like nalidaxic acid (88.88\%), ciprofloxacin $(62.90 \%)$ was detected. In disagree to this study, E.coli was reported highly sensitive to ciprofloxacin, enrofloxacin, pefloxacin and norfloxacin from Bangalore, India (Sharada et al.,2010). This rise in resistance may be due to extensive use of fluoroquinolones in intensively rared poultry production to check early chick mortality and enteritis. However, most of the E.coli isolates were sensitive to levofloxacin $(62.9 \%)$ which may be due to the fact that this drug was introduced for past few years in poultry production in India. Resistance of E.coli to tetracycline was reported in many previous studies (Sharada et al., 2010; Mane et al., 2012). The observations were similar in the present study. Susceptibility to aminoglycoside, gentamicin was also declined $(58.07 \%)$ in the present study. In contrast Sahoo et al., (2012) recorded a higher susceptibility of E.coli to gentamicin $(85.72 \%)$. Aminoglycosides like amikacin showed high sensitivity $(78.95 \%)$ in one study by Joshi et al., (2012). Highest susceptibility of E.coli was recorded with chloramphenicol $(69.36 \%)$ may be due to the negligible use of this drug in poultry. Previously Joshi et al., (2012) found $100 \%$ sensitivity of E.coli to chloramphenicol in their study. Most of the ESBL-producing E.coli were found resistant to other class of antimicrobials like 
aminoglycosides and sulphonamides in the present study. Similar findings of multidrug resistant ESBL-producing E.coli were also recorded by other workers (Kar et al., 2015). Bhave et al., (2019) reported high degree of resistance to nalidixic acid (95.89\%), tetracycline $(95.89 \%), \quad$ trimethoprim (89.04\%), colistin (82.88\%), and ciprofloxacin $(54.11 \%)$, including $\beta$-lactam antimicrobials ampicillin (84.93\%) and amoxicillin/clavulanic acid $(81.51 \%)$ by $E$. coli isolates. $\beta$-lactam antimicrobials, especially the third-generation cephalosporins, are the most common antimicrobials used for livestock and human infections. Resistance to these drugs causes occational treatment failure and use of most expensive last resort carbapenem antimicrobials like imipenem that are commonly used for human therapy. Plasmids mediated ESBLs may also carry multiple resistance genes for non- $\beta$-lactam and their indiscriminate use can lead to coselection and/or coresistance in bacteria populations (Ewers et al., 2012).

In conclusion, the present study revealed occurrence of multidrug resistant ESBLproducing E. coli in broilers of West Bengal, India with a predominance of blaCTX-M gene. Hence, poultry farms or meat products might be an important reservoir for ESBLproducing bacteria leading to farm contamination and persistent threat of spreading in humans.

\section{References}

Bhave S., Kolhe R., Mahadevaswamy R., Bhong C., Jadhav S., Nalband S., Gandhale D., Muglikar D. 2019. Phylogrouping and antimicrobial resistance analysis of extra intestinal pathogenic Escherichia coli isolated from poultry species. Turk J. Vet. Anim. Sci., 43:117-126.
Bhoomika, Shakya S., Patyal A., Gade N.E. 2016. Occurrence and characteristics of extended-spectrum $\quad \beta$-lactamases producing Escherichia coli in foods of animal origin and human clinical samples in Chhattisgarh, India. Vet. World, 9: 996-1000.

Brower C.H., Mandal S., Hayer S., Sran M., Zehra A., Patel S.J., Kaur R., Chatterjee L., Mishra S., Das B.R., Singh P., Singh R., Gill J.P.S., Laxminarayan R. 2017. The prevalence of extended-spectrum beta-lactamase-producing multidrugresistant Escherichia coli in poultry chickens and variation according to farming practices in Punjab, India. Environ. Health Perspect., 125: 077015.

Casella T., Nogueira M.C.L, Saras E., Haenni M., Madec J. 2017. High prevalence of ESBLs in retail chicken meat despite reduced use of antimicrobials in chicken production, France. Int. J. Food Microbiol., 257: 271-275.

Clinical and Laboratory Standards Institute 2017. Performance Standards for Antimicrobial Susceptibility Testing. M100-S27. CLSI, Wayne, PA, USA.

Dho-Moulin, M., Fairbrother J.M. 1999. Avian pathogenic Escherichia coli (APEC). Vet. Res., 30: 299-316.

Ewers C., Bethe A., Semmler T., Guenther S., Wieler L.H. 2012. Extended spectrum beta-lactamase-producing and AmpCproducing Escherichia coli from livestock and companion animals, and their putative impact on public health: a global perspective. Clin. Microbiol. Infect., 18: 646-655.

Ibrahim R.A, Cryer T. L., Lafi S. Q., Basha E., Good L., Tarazi Y. H.2019. Identification of Escherichia coli from broiler chickens in Jordan, their antimicrobial resistance, gene characterization and the associated risk factors. BMC Vet. Res., 15:159. 
Joshi, S., Singh R., Singh S. P.2012. Antibiotic resistance profile of Escherichia coli isolates from colibacillosis in and around Pantnagar, India.Vet. World, 5: 405-408.

Kar D., Bandyopadhyay S., Bhattacharyya D., Samanta I., Mahanti A., Nanda P.K., Mondal B., Dandapat P., Das A.K., Dutta T.K., Bandyopadhyay S., Singh R.K. 2015. Molecular and phylogenetic characterization of multidrug resistant extended spectrum beta-lactamase producing Escherichia coli isolated from poultry and cattle in Odisha, India. Infect. Genet. Evol., 29: 82-90.

Kunert Filho H.C, Carvalho D., Grassotti T.T., Soares B.D., Rossato J.M., Cunha A.C., Brito K.C.T., Cavalli L.S., Brito B.G. 2015. Avian pathogenic Escherichia coli -methods for improved diagnosis. World's Poult. Sci. J., 71: 249-258.

Kuralayanapalya S.P., Patil S.S., Hamsapriya S., Shinduja R., Roy P.,Amachawadi R.G.2019. Prevalence of extendedspectrum beta-lactamase producing bacteria from animal origin: A systematic review and meta-analysis report from India. PLoS ONE, 14: e0221771.

Lalzampuia H., Dutta T.K., Warjri I., Chandra R.(2013). PCR-Based detection of extended-spectrum blactamases (blaCTX-M-1 and blaTEM) in Escherichia coli, Salmonella spp. and Klebsiella pneumoniae isolated from pigs in North Eastern India (Mizoram). Indian J. Microbiol., 53:291-296.

Lalzampuia H., Dutta T.K., Warjri I., Chandra R.2014. Detection of extended spectrum beta-kactamases (blaCTX-M1 and bla TEM) in Escherichia coli, Salmonella sp.and Klebsiella pneumoniae isolated from poultry in North Eastern India. Vet. World, 7: 1026-1031.
Landoni M.F., Albarellos G.(2015). The use of antimicrobial agents in broiler chickens. Vet. J., 205: 21-27.

Laube H., Friese A., Von Salviati C., Guerra B. and Rossler U.2014. Transmission of ESBL/AmpC- producing Escherichia coli from broiler chicken farms to surrounding area. Vet. Microbiol., 172: 519-527.

Mane D. V., Palit M.U., Sawale G. K.2012. Antimicrobial drug resistance pattern of Escherichia coli isolated from commercial chicken. Indian Vet. J., 89: 12-14.

Nhung N.T., Chansiripornchai N., CarriqueMas J.J. 2017. Antimicrobial resistance in bacterial poultry pathogens: a review. Front. Vet. Sci., 4:126.

Olsen R.H., Bisgaard M., Löhren U., Robineau B., Christensen H.2014. Extended-spectrum $\quad \beta$-lactamaseproducing Escherichia coli isolated from poultry: a review of current problems, illustrated with some laboratory findings. Avian Path., 43: 199-208.

Page S.W.,Gautier P.2012. Use of antimicrobial agents in livestock. Rev. Sci. Tech., 31:145-88.

Quinn, P.J., Carter M.E, Markey B.K., Carter G.R. 1999. Section 2: Bacteriology. In: Clinical Veterinary Microbiology, Harcourt Publishers Limited, Spain.;pp. 118-254.

Randall, L.P, Clouting C., Horton R.A, Coldham N.G., Wu G., Clifton- Hadley F.A., Davies R.H., Teale C.J.2011. Prevalence of Escherichia coli carrying extended-spectrum $\beta$-lactamases (CTX$\mathrm{M}$ and TEM-52) from broiler chickens and turkeys in Great Britain between 2006 and $2009 . \quad J$. Antimicrob.Chemother., 66: 86-95.

Sahoo, T. K., Sahoo L., Sarangi L.N., Panda S.K., Panda H.K.2012. Prevalence, isolation, characterisation and 
antibiogram study of pathogenic Escherichia coli from different poultry farms of Odisha. J. Adv. Vet. Res., 2: 169-172.

Samanta I., Joardar S.N., Das P.K., Das P., Sar T.K., DuttaT.K., Bandyopadhyay, S.,Batabyal S., Isore D.P. 2014. Virulence repertoire, characterization and antibiotic resistance pattern analysis of Escherichia coli isolated from backyard layers and their environment in India. Avian Dis.,; 58: 39-45.

Samanta, I., Joardar S.N., Das P.K., Sar T.K. 2015. Comparative possession of Shiga toxin, intimin, enterohaemolysin and major extended spectrum beta lactamase (ESBL) genes in Escherichia coli isolated from backyard and farmed poultry. Iranian J Vet.Res.,16: 90-93.

Sharada, R., Wielfred R.,Thyageeswaran M.2010. Isolation, characterization and antibiotic resistance pattern of Escherichia coli isolated from poultry. Am. Eurasian J. Sci. Res., 5: 18-22.

Shiva Shankar T. V., Sharma A., Grover Y.P. 2010. Studies on different virulence factors of avian pathogenic Escherichia coli. Haryana Vet. 49: 45-47.

Shrivastav A, Sharma R.K., Sahni Y.P., Shrivastav N., Gautam V., Jain S.2016. Study of antimicrobial resistance due to extended spectrum beta-lactamaseproducing Escherichia coli in healthy broilers of Jabalpur. Vet. World, 9: 1259-1263.
Thakur R., Kumar Y., Singh V., Gupta N., Vaishv B., Gupta S.2016. Serogroup distribution, antibiogram patterns and prevalence of ESBL production in Escherichia coli. Indian J Med Res., 143: 521-524.

Walia K., Sharma M., Vijay S., Shome B.R.2019. Understanding policy dilemmas around antibiotic use in food animals \& offering potential solutions. Indian J Med Res., 149:107-118.

Wasyl, D., Hasman, H., Cavaco, L.M., Aarestrup, F.M.2012. Prevalence and characterization of cephalosporin resistance in nonpathogenic Escherichia coli from food-producing animals slaughtered in Poland. Microb. Drug Resist., 18: 79-82.

Weill F.X, Lailler R., Praud K., Ke'Rouanton A., Fabre L., Brisabois A., Grimont P.A.D., Cloeckaert A.(2004a). Emergence of extended-spectrumlactamase (CTX-M-9)-producing multiresistant strains of Salmonella enterica serotype Virchow in poultry and humans in France. J.Clin.Micro., 42: 5767-5773.

Weill F.X., Demartin M., Tande D., Espie E., Rakotoarivony I., Grimont P.A.D (2004b). SHV-12-like extendedspectrum-lactamase-producing strains of Salmonella enterica serotypes Babelsberg and Enteritidis isolated in France among infants adopted from Mali. J.Clin.Micro., 42: 2432-2437.

\section{How to cite this article:}

Susmita Pal, Samir Dey, Kunal Batabyal, Abhiroop Banerjee, Siddhartha Narayan Joardar, Indranil Samanta and Devi Prasad Isore. 2020. Prevalence and Characterization of Extended Spectrum Beta Lactamase Producing Escherichia coli from Broilers. Int.J.Curr.Microbiol.App.Sci. 9(03): 594-602. doi: https://doi.org/10.20546/ijcmas.2020.903.070 